\author{
Cadernos de \\ ESTUDOS LINGUIISTICOS - (58.3), Campinas, pp. 535-549 - set./dez. 2016
}

\title{
FOUCAULT NOSSO PRÓXIMO
}

\author{
PEDRO DE SOUZA ${ }^{1}$
}

\begin{abstract}
RESUMO: Neste texto, proponho uma análise pontual de fragmentos de fala de Michel Foucault enfocando o emprego que o filósofo faz do pronome "nós". O objetivo é mostrar a maneira singular com que o pensador francês se torna próximo das realidades históricas, políticas e sociais de que se ocupa, mesmo quando se encontra local e temporalmente distante dos acontecimentos em que se engaja. Para tanto, valho-me da teoria enunciativa de Benveniste, a fim de explicitar os vários momentos em que Foucault se constitui como sujeito militante, inclusive as ocasiões em remete a uma cultura muito diferente da sua. Atenho-me especificamente ao uso do "nós" para mostrar como o filósofo francês constituía-se, em seus atos de enunciação, enquanto "intelectual específico", contrapondo-se a uma posição de discurso filosófico que se pretendia universal. Concluo que, em Foucault, o sujeito que se torna próximo está atrelado a um ato inclusivo e co-extensivo de descentramento de si.
\end{abstract}

Palavras-chave: enunciação, singularidade, subjetividade, discurso.

RÉSUMÉ:Dans cet article, nous proposons une analyse spécifique des fragments de discours de Michel Foucault, focalisée sur l'emploi que le philosophe réalise du pronom " nous ». Le but est de montrer la façon singulière et unique dont le penseur français aborde les réalités historiques, politiques et sociales auxquelles il fait référence, même lorsqu'il est géographiquement ou temporellement éloigné des événements qui font l'objet de sa réflexion. Nous conclurons que chez Foucault, l'homme qui s'approche d'autrui lui est lié par un acte coextensifde descentrement de soi.

Mots-clés : énonciation, unicité, subjectivité, discours

\section{O COMUM DE NÓS, OS MODERNOS}

O que pretendo expor neste artigo é um prolongamento da reação raivosa de Alain Brossat ${ }^{2}$ contra as críticas dirigidas a Michel Foucault no campo dos estudos pós-coloniais. É que, para dar conta de um pensamento libertário no âmbito das práticas culturais, tidas como ainda reféns do contexto colonialista, observa-se a formação de uma corrente de críticos contemporâneos que rejeita o pensamento foucaultiano, por considerá-lo indiscutivelmente "eurocêntrico" e até mesmo "ocidentalista".

\footnotetext{
${ }^{1}$ Professor Titular na Universidade Federal de Santa Catarina

${ }^{2}$ Alain Brossat, «Quand Foucault dit «nous» ... ». In http://appareil.revues.org/1265. Acesso em $03 / 02 / 2016$
} 
Não é tanto a contra-argumentação de Brossat que quero retomar aqui. É que, na reação deste autor acerca do que considera argumentativamente mal elaborado nos escritos que rejeitam a filosofia de Foucault, o que atraiu minha atenção foi a maneira de se servir dos próprios escritos foucaultianos para retirá-lo da posição militante com que têm sido recusadas certas ideias, por não se adequarem às questões específicas fora da Europa.

Nas próprias palavras de Alain Brossat, sua decisão foi a de retornar sobre o que em Foucault se constitui como uma "escolha original". Nesta expressão, Brossat retoma a fórmula do próprio filósofo. Ele explicita assim a ideia de "um gesto primeiro" equivalendo à atitude de não adotar a postura do saber filosófico universalmente detentor de todo conhecimento. Nisto consiste o fundamento do trabalho foucaultiano, a saber, um certo modo de delimitar o espaço, mais que o território, e de ligar a esta abordagem topológica uma arte de enunciar um "nós" inteiramente singular.

Tal é a originalidade de Foucault, que explica o fato de ele sempre repetir "não sou filósofo". Em verdade, é um certo modo de fazer filosofia que ele rejeita, para tomar distância não tanto dos conteúdos dos enunciados proferidos, mas da forma com que o sujeito toma a palavra, alienando-se das condições materiais de seu dizer. Estas, ao contrário, têm a ver com a historicidade, a temporalidade, a espacialização que apontam para o sujeito enunciante enquanto coordenadas constitutivas e contemporâneas ao seu dizer. Descreve-se aí o quadro das condições de possibilidade sob as quais o discurso funciona na divisão entre o verdadeiro e o falso.

Brossat ressalta, sobre este ponto, a função fundamental do procedimento do recorte que consiste em delimitar, sob algum aspecto preciso e singular, o objeto ou tema de estudo. Assim, explica Brossat, quando Foucault cria o título de seu primeiro livro, História da loucura na época clássica, segmenta a temática em duas partes: a primeira, uma expressão nominal - 'história da loucura' - designa o objeto de que trata a obra; a segunda expressão, uma locução adverbial de tempo - "na época clássica" -, delimita o ponto de vista a partir do qual o objeto é abordado. Assim, o filósofo estabelece o recorte mediante o qual trata historicamente do tema da loucura, marcando aí a perspectiva singular que caracteriza sua investigação.

Do mesmo modo, na composição do nome de sua segunda grande obra, As palavras e as coisas - uma arqueologia das ciências humanas, a divisão do título em duas partes mostra que não se trata de enunciar o estudo das ciências em geral, mas de abordá-las sob um aspecto restrito, recortando sua constituição em uma região histórica do saber. O caso é, portanto, deter-se sobre um objeto, genericamente proposto em algum domínio disciplinar, e recortá-lo, excluindo todos os outros, sem que esses outros sejam ignorados ou rejeitados. A expressão nominal - uma arqueologia das ciências humanas - com função de delimitar o ponto de vista sobre o objeto - as palavras e as coisas - termina por presentificar outras perspectivas excluídas além daquela que foi adotada para investigação. Tudo se passa como se, em vez de ocupar um lugar genérico e universal de visibilidade e enunciabilidade, ele delimitasse uma circunstância ou espaço a partir do qual se pode recortar o objeto na diferença com que é proposto para o saber. Isto não é possível quando se adota o ponto de vista universalizante, apagando a visão da multiplicidade. 
Cadernos de ESTUDOS LINGUÍSTICOS (58.3) - set./dez. 2016

Devo agora saltar os detalhes da análise rigorosa de Alain Brossat. Meu propósito é destacar, no trabalho deste autor, o funcionamento do emprego do pronome "nós", necessariamente aliado ao uso de indicadores linguísticos em sua função dêitica, ou seja, as unidades indiciais que dão conta de marcar a situação em que se coloca aquele que enuncia.

Cabe desde já advertir que me guiarei pela teoria enunciativa de Émile Benveniste, notadamente no que diz respeito ao emprego do plural do pronome de primeira pessoa, "nós". O intuito é tornar visível, na e pela linguagem, os vários momentos em que Foucault se constitui como sujeito militante. Considero, sobretudo, a maneira como o filósofo se marca, mediante o emprego do plural de primeira pessoa, como o intelectual francês dirigindo-se a interlocutores situados em outra cultura, por exemplo, a oriental. Minha ideia é desenvolver uma análise de base enunciativa e discursiva, explicitando que é sobretudo pela linguagem que esse filósofo francês aponta para si como um "intelectual específico". O emprego do "nós" torna-se portanto a dêixis de uma subjetividade pensante constituindo-se na contramão de uma posição enunciativa que se pretendia universal, no âmbito do tradicional discurso filosófico, conforme devo demonstrar mais adiante.

Neste ponto, retomando o que apresentei sobre a composição do título de duas grandes obras foucaultianas, quero ressaltar o funcionamento do aposto quando este é vinculado ao pronome "nós". Exemplos desta modalidade da construção são típicas na escrita e na fala de Foucault: "Nós, os modernos, começamos a nos dar conta de que, sob a loucura, sob a neurose, sob o crime, sob as inadaptações sociais, corre uma espécie de experiência comum da angústia". A referência dêitica pessoal do pronome "nós" delimita-se situacionalmente no recorte temporal designado pelo aposto "os modernos". Não se trata, para o enunciante, de incluir todos os que o escutam ou que o leem; é justamente do "nós", situado entre "os modernos", de que se trata nesse fragmento do livro História loucura (p. 122).

É interessante notar que o qualificativo "moderno" funciona extensivamente nas referências espaciais, tais como em "sociedades modernas"3, "poderes modernos"4, indicando a maneira pela qual o filósofo desloca-se de uma "topologia objetiva" para uma "topologia subjetiva", movimentando a instância linguisticamente pessoal e espacial da enunciação de um "aqui e ali" para um "nós e não os outros" . Brossat (op. cit. p. 6) considera que, com esta operação, fica marcado, na escrita de Foucault, o propósito de atrair o leitor, fazendo-o pensar o espaço do moderno como a condição sob a qual todos nós fomos constituídos como sujeitos. Em síntese, o adjetivo moderno recorta o espaço, situando-o na relação com outros. Desta maneira,

${ }^{3} \mathrm{O}$ objeto de minha história é um pouco a colonização imperialista no interior do espaço europeu: de que maneira as formas de dominação sobre os indivíduos ou sobre algumas categorias de indivíduos se estabeleceram e como elas puderam fazer funcionar as sociedades ocidentais, as sociedades modernas (grifo meu)? (FOUCAULT, Michel. "A cena da filosofia”. In:Ditos e escritos VII, 2011. p. 233)

${ }^{4}$ Se o genocídio é, de fato, o sonho dos poderes modernos (grifo meu) não é por uma volta, atualmente, ao velho direito de matar; mas é porque o poder se situa e se exerce ao nível da vida, da espécie, da raça e dos fenômenos maciços de população. (Foucault, História da Sexualidade I. A vontade de saber. 1979 , p. 129)

${ }^{5} \mathrm{Cf}$. (...) Aqui e ali, (grifo meu) no conhecimento da loucura e no reconhecimento do louco, não é a mesma virtude que insidiosamente se desenvolve e representa o papel da razão? (Foucault, História da Loucura, p. 229) 
"o recorte visa aqui a fazer aparecer as condições de um "nós" (sempre situado, delimitado, porém, de um modo que não é mais tão distintamente "geográfico"), do qual Foucault descreveu a particularidade, a singularidade "histórica" em seu texto/comentário da famosa "Réponse" de Kant à questão "Qu'est-ce que les Lumières?". 6

Vê-se como Alain Brossat aborda em Foucault a propriedade do gesto de enunciação que situa e constitui o sujeito que enuncia em relação ao espaço e ao tempo de sua fala. A especificação do espaço, a meu ver, não apenas propõe a topografia do objeto, mas do próprio sujeito enunciante, conduzido a situarse relativamente ao espaço-tempo que é continente daquilo de que fala. Mas o decisivo, diz Brossat, na maneira de Foucault se marcar enunciativamente em sua escrita analítica, é a articulação entre os dêiticos "aqui" e "nós". É importante citar como o autor explica esta relação de espaço e pessoa.

\begin{abstract}
A passagem do "momento" da descrição topológica ao da proliferação do "nós", "nosso" etc. assinala uma inflexão decisiva do gesto filosófico. Não é por nada que o uso do "nós" vai se intensificando, da História da loucura à Vontade de saber, um ensaio que se abre com esta frase: “... por muito tempo, teríamos suportado um regime vitoriano, e a ele nos sujeitaríamos nós ainda hoje" ${ }^{\text {" }}$ e que se escreve inteiramente sob o signo desse plural (coletivo) e dos pronomes possessivos que aí se reportam. ${ }^{8}$
\end{abstract}

Nesta perspectiva aberta no texto de Alain Brossat, tomo o ato de enunciação e nele o emprego do "nós" como objeto de análise capaz de mostrar a maneira pela qual o autor de $O$ nascimento da clínica converte-se, sem parar, em pensador próximo, independente do espaço em que se situa no tempo de sua fala. O que coloco em destaque é a relação do aqui/nós construída em termos de interenunciação. Este é o ponto de vista a que Brossat nos conduz quando considera as variações do emprego do pronome "nós", que, nos escritos de Foucault, permanece constante de uma obra para outra.

(...) aqui e ali (grifo meu), na ordem da especulação e na ordem da instituição, no discurso e no decreto, na palavra e na palavra de ordem - por toda parte onde um elemento portador de signo pode assumir, para nós, valor de linguagem. (Foucault, História da Loucura, p. 277)

(...) Aqui e ali (grifo meu) veem-se os mesmos esforços para a retomada de certas práticas do internamento no grande mito da alienação, exatamente aquele que Hegel deveria formular alguns anos mais tarde, extraindo com todo rigor a lição conceitual daquilo que havia ocorrido no Retiro e em Bicêtre. (Foucault, História da loucura, p. 524)

6 "La découpe vise ici à faire apparaître les conditions d'un "nous" (toujours situé, délimité, mais sur un mode qui n'est plus aussi distinctement "géographique") dont Foucault a décrit la particularité, la singularité "historique" dans son texte/commentaire de la fameuse". (BROSSART, op. cit. , p. 5)

${ }^{7}$ FOUCAULT, M. 1079, op. cit. p. 9.

8 "Le passage du "moment" de la description topologique à celui de la prolifération des "nous", "nos", "notre" (etc.) signale une inflexion décisive du geste philosophique. Ce n'est pas pour rien que l'usage du "nous" va en s'intensifiant, de L'histoire de la folie à La volonté de savoir, un essai qui s'ouvre sur cette phrase: "Longtemps, nous aurions supporté, et nous subirions aujourd'hui encore, un régime victorien" et qui s'écrit tout entier sous le signe de ce pluriel (collectif) et des pronoms possessifs qui s'y rapportent". (Brossar, op. cit. p. 5) 
No momento em que Foucault escreve História da sexualidade I. A vontade de saber, marca-se, mediante a primeira pessoa do plural, um "eu", ampliado designando-o como francês, europeu, ocidental. Trata-se de implicar o leitor de modo menos frio e formal, como por exemplo, o faz empregando "nós" em suas análises arqueológicas contidas em As palavras e as coisas. Ao contrário, em História da sexualidade I. A vontade de saber, o emprego de "nós" é parte de uma estratégia enunciativa em que urge partilhar com o leitor uma pertença, a saber, o referencial cultural de formação do sujeito na relação com suas práticas sexuais. Vê-se aí o envolvimento do leitor em um processo de identificação em que, interpelado como francês e ocidental, é conduzido a criticar as condições que fizeram dele, incluído o autor que lhe fala, um sujeito pecador. Daí o efeito enunciativo do emprego do "nós" em enunciados como: “... mas seria preciso se perguntar também porque hoje em dia nos culpamos tanto por ter outrora feito dele ( o sexo) um pecado?"'.

Na enunciação foucaultiana, não há lugar para uma posição restrita de sujeito. Mesmo quando se situa em um horizonte espacial e temporal não-coincidente com o de seus destinatários, os adjetivos "europeu" e "ocidental", com os quais Foucault recorta uma experiência de sexualidade, convoca certo "nós" em uma contemporaneidade comum, ou seja, a do tempo e espaço de problematização de quem somos e das condições que nos levaram a ser como somos.

É o que se pode depreender em suas manifestações, em momentos em que se ocupa e se envolve em questões políticas e sociais que não lhes dizem imediatamente respeito, como a que o levou a seguir como jornalista os acontecimentos da revolução iraniana em 1978. Em "Uma revolta a mãos nuas", Foucault, quando termina seu texto falando em primeira pessoa do plural, coloca-se em um lugar de modo a incluir seus leitores no ato de enunciar. É por aí que se pode analisar o emprego da primeira pessoa - no plural - como estratégia que amplia a implicação daquele que fala comprometendo o ouvinte, não para convencê-lo, mas para fazê-lo ver de outra maneira o que acontece.

\footnotetext{
Mohamed Reza partirá ou não? (...). A questão é a de saber quando a vontade de todos vai ceder lugar à política, a questão é a de saber se ela o quer e se deve fazê-lo(...) Confessemos que estaríamos nós, ocidentais, mal colocados para dar, sobre esse ponto, um conselho aos iranianos ${ }^{10}$.
}

No quadro de referência desta enunciação, estão em cena o autor e seus leitores. "Nós" reúne posições virtualmente díspares, sem que as disparidades sejam diluídas. Por outro lado, sem ter lugar de tomada da palavra no diálogo composto por Foucault, há os iranianos, referidos como objeto de que se fala - "um conselho aos iranianos". Destaco aqui um jogo complicado de interlocução em que o "nós" funciona de modo exclusivo, ou seja, coloca em cena o filósofo dirigindo-se a seus leitores, e exclui desta interlocução os personagens a que se refere.

\footnotetext{
${ }^{9}$ FOUCAULT, M. Op. cit., 1979, p. 14.

${ }^{10}$ FOUCAULT, M. “Uma revolta a mãos nuas". In Ditos e escritos VI. 2010, p. 241, 244.
} 
No fragmento em destaque, realço o funcionamento do plural de primeira pessoa numa operação que desloca autor e leitor para o espaço e tempo do outro, configurando o ato coletivo do pensar pela diferença. Tem-se aí o modo de o pensador francês enredar seus interlocutores numa experiência histórica diferencial acerca das revoltas contra o governo instituído em épocas diversas. A proximidade que se produz entre enunciador e destinatário, nesta operação de emprego do "nós", opõe o "lá" da revolta do Irã em 1978 ao "aqui" da posição dos ocidentais, em princípio, situados espacial e politicamente fora do conflito.

Foucault preserva, assim, a mesma atitude que o faz próximo de todos os interlocutores, não importa quem eles sejam. A singularidade de sua reflexão consiste em se desvencilhar de uma pretensão universalizante e se aproximar do presente colocado em questão. Falando pontualmente do que se passa no Irã, o uso do "nós" está longe de configurar um mero proselitismo de quem visa persuadir. Em quadros como esses, Foucault, quando diz "nós", mais que conciliação, provoca perturbação em seu interlocutor. Isto porque as condições de sua enunciação envolvem um espaço ampliado de destituição de si. Ampliar, mediante o uso da primeira pessoa do plural, é levar o dizer a produzir inclusão conectando as vozes de quem fala com as de quem ouve.

Descreve-se aí um inusitado convite ao pensar. Nesse convite, o "nós" fica proposto como soma do "eu "+" tu". Ambos tornam-se próximos sem que cada um se obrigue a renunciar ao que foi levado a ser. O "nós", partícula linguística de dilatação do "eu", não sentencia façamos assim. Apenas interroga: e se considerássemos de modo outro este problema? Brossat não cansa de insistir:

É, portanto, um "nós" de interpelação que "nos" convida a nos descentrar em relação às evidências fundadoras de nossa comum constituição ("Nós outros supostos, supostos vitorianos..."), a desconstruir ou destricotar malha por malha o tecido dessa partilha falaciosa de sensibilidades de que é feito "o que nós somos" (sexualmente reprimidos, ávidos de nossa "liberação"...)"

E Foucault é a afirmação da diferença libertária. Sua postura dita em primeira pessoa do plural nunca pode ser comparável ao "nós" de quem se põe como o dono da verdade, ainda que se trate de combater tiranias sanguinárias. Foucault situa-se no avesso disso. A distância enunciativa entre o modo centrado de dizer "nós" e aquele despojado de si em seus textos é que o torna paradoxalmente próximo, mesmo daqueles a quem veementemente cabe denunciar o autoritarismo do mais forte contra o mais fraco. O emprego do "nós" instaura, na superfície dos textos foucaultianos, um ponto de convergência que o aproxima de polaridades opostas. Ele pode tanto incluir em seu espaço de fala os algozes como as vítimas porque, cada um, conforme a urgência e especificidade de seu problema, deve destituir-se de si mesmo para promover a libertação relativamente à história que os constituiu como são.

${ }^{11}$ C'est donc un "nous" d'interpellation qui "nous" convie à nous décentrer par rapport aux évidences fondatrices de notre commune constitution ("Nous autres, supposés victoriens... "), à déconstruire ou détricoter maille par maille le tissu de ce partage fallacieux des sensibilités dont est fait "ce que nous sommes" (sexuellement réprimés, avides de notre "libération"...). 
Cadernos de ESTUDOS LINGUÍSTICOS (58.3) - set./dez. 2016

Nesse ponto, é preciso assinalar que os atos de tomada da palavra se equivalem, quando realizados tanto no plano escrito quanto no oral. Brossat leva em conta também a enunciação escrita de Foucault. Mas, no exercício oral, o emprego do "nós" diz muito do ato de interpelar seus interlocutores deslocando-os do conforto de suas certezas.Talvez aí aquele que se dirige a outros dizendo "nós" converta-se em uma voz estranhamente próxima. Proximidade no reconhecimento de posições autonomamente arroladas - os que debatem contra ou a favor. Estranheza pela instauração de um espaço inusitado de reflexão. Daí advém o espectro do diferente, do singular. Trata-se, diz Brossat, da arte de fazer emergir singularidades, na vocação que elas têm de se colocar uma em relação com as outras, estabelecendo modalidades de harmonia pautada pela ação libertária.

É um certo cuidado e respeito para com seu destinatário que distingue a maneira pela qual Michel Foucault emprega o "nós", especialmente nas conversas face a face. A apropriação desta forma pronominal serve para discutir um problema, evitando a polêmica e respeitando o fato de que o interlocutor não experimenta do mesmo jeito a questão discutida. Numa conferência proferida no Japão, tratando das condições da prisão, o emprego do plural da primeira e segunda pessoas é um traço linguístico indicativo do contraste na experiência partilhada por Foucault e por seus ouvintes japoneses. Na ocasião, o filósofo se reportou aos problemas da criminalidade, da penalidade e da prisão, atentando para o quanto essas questões se colocavam em termos muito diferentes para ele mesmo e para sua plateia japonesa.

Eu havia proposto, dentre os possíveis temas de conferência, uma entrevista sobre as prisões, sobre o problema particular das prisões. Fui levado a renunciar a ele por diversos motivos; o primeiro é que, após três semanas de minha estada no Japão, me dei conta de que o problema da penalidade, da criminalidade, da prisão se colocava em termos muito diferentes na nossa sociedade e na de vocês (grifo meu) ${ }^{12}$.

Aí, para recortar as condições espaciais irredutíveis que situam a mesma questão para o conferencista francês e para seus interlocutores japoneses, foi preciso empregar respetivamente os possessivos "na nossa sociedade" e "na de vocês". Mas nem por isso, na sua função própria de marcador de pessoa verbal, o "nós" deixa de implicitamente atuar nesta enunciação de maneira dominante, pois, contrastando os possessivos "nossa" e "de vocês", Foucault evita transpor para a sociedade japonesa o modelo analítico baseado na experiência que teve das prisões na Europa, e instaura um lugar comum de questionamento sem que os interlocutores tenham de se retirar de suas respectivas vivências.

Por este modo de juntar o "eu" com o "tu", ampliando o lugar enunciativo do destinador para dar entrada ao destinatário como co-enunciador, a experiência francesa e a japonesa, relativamente ao sistema penal que era tema da conferência previamente preparada por Foucault, podem coexistir no horizonte da problemática mais geral do poder. A conversa sobre as vicissitudes do poder ao longo da história configura, portanto, espaço de enunciação em que o filósofo francês pode, sem constrangimento, empregar "nós" incluindo seu interlocutor, justamente porque este tem do poder uma outra experiência.

${ }^{12}$ FOUCAULT, M. “Afilosofia analítica da política (1978)”. In: Ditos e escritos V.2004.,p. 37-55. 


\section{NÓS, QUE ESTAMOS PRESOS AO DORSO DE UM TIGRE ${ }^{13}$}

É o caso agora de considerar o princípio, propalado por Foucault desde a aurora de sua carreira, isto é, o de que há linguagem. Levando a sério esta perspectiva, pode-se afirmar que, quando se dirige a seus interlocutores, o autor de $A$ ordem do discurso não visa simplesmente transmitir pensamentos, afetos, ou veicular sua adesão à causa de outro. Ainda que seja de modo não calculado - até certo ponto necessário para que haja interlocução -, ao falar, Foucault se marca na ação de se destituir da posição de sujeito fabricado na e pela história.

Digamos, desta forma, que opera o princípio por ele próprio proposto, ao lado de Roland Barthes e de Jacques Lacan, de que a linguagem antecede a toda relação interpessoal. Em termos precisos, não é possível que haja subjetividade antes e fora da linguagem. O sujeito enunciante é efeito da linguagem, esfera em que tem lugar a enunciação. Por isso, em se tratando de interlocução, em pronunciamentos dados no âmbito do ativismo político, Foucault não pressupõe a consciência do outro a ser desperta, mas a problematiza para poder deslocá-la mediante uma maneira de enunciar que não produz evidências, mas as desconstrói. Mesmo quando o "eu" é o pronome que marca o ato individual de tomar a palavra, logo se propõe juntando-se ao "não-eu" para abrir a cena da interferência em um espaço no qual o "nós" efetiva-se como sujeito da enunciação.

E ele diz: "Procuro provocar uma interferência entre nossa realidade e a que sabemos de nossa história passada. Se tenho sucesso, essa interferência produzirá reais efeitos em nossa história presente"14. O emprego dos pronomes pessoais, ora no singular, ora no plural, deve produzir o efeito de incluir o "tu" no espaço enunciativo em que se arquiteta a empresa crítica que Michel Foucault se propõe. Se o "eu" predomina, na cadeia da fala, só o faz atuando como bússola a indicar permanentemente o mesmo terreno em que todos são adjuntivamente aportados.

Nesse ponto, é preciso trazer para esta análise os fundamentos da noção de pessoa pronominal na teoria da enunciação proposta por Émile Benveniste, a que apenas aludi antes. Quando se trata da flexão gramatical de número, Benveniste parte da premissa de que

\footnotetext{
... nos pronomes pessoais, a passagem do singular para o plural não implica apenas uma pluralização. Além do mais, cria-se em inúmeras línguas uma diferenciação da forma verbal da primeira pessoa plural sob dois aspectos distintos (inclusivo e exclusivo), que denuncia uma complexidade particular. (Benveniste, 1995, p. $)^{15}$
}

\footnotetext{
${ }^{13}$ Alusão ao fim do último parágrafo do livro As palavras e as coisas, p. 345.

${ }^{14}$ FOUCAULT, M. "Foucault estuda a razão de Estado". In Ditos e escritos IV. p. 321 [os grifos são meus].

15 BENVENISTE, É. "Estrutura das relações de pessoa no verbo francês". Problemas de Lingüistica Geral II., 1995.
} 
O que está em questão na proposição de Benveniste é a supremacia da primeira pessoa flexionada no singular. Há um aspecto notável que marca o fato de a língua propor palavras diferentes para se referir à pessoa verbal: para indicar primeira pessoa no singular, usa-se "eu"; no plural, "nós". Quando a referência vai para a segunda pessoa do singular, a palavra é "tu", para o plural de segunda pessoa, usa-se "vós" pronomes pessoais, no entender de Benveniste, é suficiente para explicar porque os pronomes não participam dos mecanismos linguísticos comuns que se adotam para expressar o plural dos nomes.

Para a análise que estou aplicando às emissões orais ou escritas de Michel Foucault, o mais pertinente é anotar dois princípios que regem o funcionamento enunciativo do contraste eu/nós. Primeiro, o fato de que, segundo Benveniste, a unicidade e a subjetividade são elementos constitutivos do "eu". O segundo princípio é uma consequência do primeiro, a saber, que o traço unitário e subjetivo do "eu" torna contraditória a pluralização dessa forma pronominal. Claro, trata-se do pronome "eu" apreendido na sua função enunciativa, ou seja, a de indicar não o sujeito sintático ao nível da frase, mas o ato individual que dá lugar à fala. Benveniste argumenta que

\begin{abstract}
Se não pode haver vários "eus" concebidos pelo próprio "eu" que fala, é porque "nós" não é uma multiplicação de objetos idênticos, mas uma junção entre o "eu" e o "nãoeu", seja qual for o conteúdo desse "não-eu". Essa junção forma uma totalidade nova e de um tipo totalmente particular, no qual os componentes não se equivalem: em "nós" é sempre "eu" que predomina, uma vez que só há "nós" a partir de "eu" e esse "eu" sujeita o elemento "não-eu" pela sua qualidade transcendente. A presença do "eu" é constitutiva de "nós".
\end{abstract}

Não quero falar aqui da afinidade teórica que pode haver entre Michel Foucault e Émile Benveniste. Não há sequer registro, a não ser paratextual ${ }^{17}$, de que o primeiro tenha lido o segundo. De qualquer modo, a formulação benvenistiana sobre o funcionamento enunciativo do "nós" como junção do "eu" com o "não-eu" permite nuançar com maior clareza a maneira com que Foucault emprega "nós" em muitos de seus proferimentos.

${ }^{16}$ Lembrando que no português do Brasil, em vez de "tu" ou "vós", conforme a região, empregam-se as variantes "você/vocês", para, respectivamente, empregar segunda pessoa do singular ou do plural.

${ }^{17}$ A este respeito, dois testemunhos servem de ponto de partida. No momento em que transferia para a Biblioteca Nacional de Paris os manuscritos pessoais de Michel Foucault, Daniel Deferi teria encontrado um livro de Émile Benveniste na biblioteca de Foucault. Martin Rueff, editor da obra L'Archéologie du savoir, confirmou uma influência muito provável de Benveniste sobre Foucault. Com o artigo que aqui apresento, lanço um primeiro movimento para, além da prova histórica e intelectual, estabelecer uma relação entre a concepção de enunciação em Benveniste e em Foucault, marcando proximidades e diferenças. Também Giorgio Agamben aventa a possibilidade deFoucault ter lido Benveniste para cunhar seus conceitos de função enunciativa e posição de sujeito (AGAMBEN, 2008) 
Na conferência realizada no Japão sobre a analítica do poder, como mencionei antes, ao contrapor os possessivos "nossa sociedade" e "a de vocês", a junção do "eu“" com o "não-eu" faz com que Foucault marque a si mesmo como francês e estabeleça, pela enunciação assim marcada, o estatuto de seu interlocutor japonês. Este fica indicado como o porto alheio do qual o enunciador se aproxima mediante a alusão da não-coincidência mútua entre o "eu" e o "não eu".

Talvez, a esta altura, valha usar destas considerações de Benveniste sobre o plural de primeira pessoal para justificar o que propus acima acerca da predominância do "eu" como operador de subjetividade. Juntar "eu" e "não eu" não conduz a produzir vários eus, mas sim alargar o espaço enunciativo do "eu", que se dilata formando uma modalidade outra de ação intersubjetiva. A predominância do "eu”, nesta operação, tem a ver com a partilha de vozes em que o "nós" resulta da presença estendida do "eu". Mas o que é exatamente em Foucault este trabalho de submeter o "não eu" à "experiência de enunciar à maneira do "eu"?

Benveniste remete à transcendência do "não eu" em termos kantianos ${ }^{18}$. Mas Foucault adota um viés neokantiano e, em vez de adotar a perspectiva da transcendência, prefere propor o a priori histórico. Assim, quando o filósofo francês diz "nós", o " não-eu" somado ao "eu" tem a ver com o a priori histórico da diferença, da heterogeneidade, sob o qual o "eu" se junta ao "não eu" perfazendo o "nós". É sempre a diferença, a singularidade que vem como o primado desta junção. A meu ver, nisso consiste a realidade do "não eu", na instância enunciativa em que Foucault se aproxima das realidades de que se ocupa quando diz "nós" - "nosso olhar se furta a nós mesmos no momento em que olhamos"19.

É interessante reparar que o pronunciar-se em primeira pessoa do plural comporta uma ação enunciativa que torna mais ampla a perspectiva do olhar/falar, que uma vez liberado de si mesmo, no limiar do espaço ampliado da enunciação, dá lugar a alternantes visões. Em termos irredutivelmente diferenciais, "nós" indica um procedimento de ampliação do escopo do sujeito enunciante, tornando factível a proximidade do filósofo em relação a seus interlocutores e seus horizontes particulares de problematização.

${ }^{18}$ É Guillaume Paugam quem chama atenção para esta proximidade entre o Eu transcendental como sujeito a priori do pensamento proposto por Emmanuel Kant e o Eu como indicação linguística do sujeito da enunciação. Ocorre que, preocupado com o correlato linguístico da subjetividade, "Benveniste parece não distinguir entre uso transcendental e o uso linguístico do "Eu", ao passo que Kant apenas considera o valor do pronome de primeira pessoa como marcador do sujeito transcendental. Ou seja, Kant e Benveniste se opõem tomando respectivamente o Eu como correlativo da faculdade de pensar, ou como indicador da faculdade de enunciar (Texto!, julho 2008, vol. XIII, n³). De minha parte, quero assinalar em Foucault a subjetividade como função enunciativa que não releva nem do pensamento como faculdade superior, nem da língua como pura estrutura formal, mas de atos de enunciação assentados no a priori histórico. (Sobre este conceito, conferir. FOUCAULT, A Arqueologia do Saber, p. 146)

${ }^{19}$ Aqui escutamos Foucault envolver o leitor como cúmplice no ato de olhar e descrever detalhes do quadro "As meninas", de DiegoVelázquez. É na referência a "nós”, os modernos, que o "eu” se junta ao "não eu". (Cf. As palavras e as coisas, p. 20.) 
Se adoto essa visão de linguagem como ação em torno da teoria benvenistiana da enunciação, é justamente para demonstrar que, quando Foucault se pronuncia empregando o pronome "nós", seja em seus escritos, seja de viva voz, fala próximo a todos aqueles com os quais interage e a quem se dirige no tempo presente. $\mathrm{Na}$ pluralização do "eu”, nos termos de Benveniste, o que se opera é não a multiplicação de eus, mas sim a amplificação do gesto enunciativo linguisticamente indicado na pessoa verbal. É importante não perder de vista esta função ampliadora do "eu" contida em "nós", se pretendemos apurar o sentido de proximidade que carrega consigo a construção de uma perspectiva outra de assentamento dos diferentes liberados das amarraras que assujeitam.

Sabe-se que, para o autor de Vigiar e punir, em ativismos pontuais como o do GIP ${ }^{20}$, era crucial não falar pelos presos. Contudo, havia a urgência do engajamento mais amplo, mediante uma palavra de ordem marcada pelo emprego do pronome "nós". Esta inflexão enunciativa era a nota de base a ser emitida para fazer reverberar o grito da revolta. Se o que estava em pauta era o sofrimento do outro, como conclamar a opinião pública a se aproximar e a tomar parte em tal drama? É o que pode ser atestado no primeiro paragrafo do Manifesto do GIP:

\footnotetext{
Nenhum de nós (grifo meu) pode ter certeza de escapar à prisão. Hoje, menos do que nunca. Sobre nossa vida do dia a dia, o enquadramento policial estreita o cerco: nas ruas e nas estradas; em torno dos estrangeiros e dos jovens. O delito de opinião reapareceu: as medidas antidrogas multiplicam a arbitrariedade. Estamos sob o signo do 'vigiar de perto' (Foucault, 2003, p. 2.) $)^{21}$
}

Nota-se aí que o dizer em primeira pessoa do plural é índice de um corpo inteiro tornando-se próximo e co-extensivo ao que se passava. Foucault entrava em manifestações sem que necessariamente estivesse diretamente envolvido nas razões da revolta. Nem por isso permanecia em silêncio, nem deixava de se marcar, assumindo-se nas palavras que proferia. $\mathrm{O}$ drama vivido nas prisões era também o seu e de todos os outros: nenhum de nós pode ter certeza de escapar à prisão. Daí o endereçamento inclusivo do emprego da primeira pessoa no plural. O pronome nós, nesse caso, indica a ampliação de um processo de subjetivação que não se define, conforme apresentei via Émile Benveniste, pelo acréscimo de identidades individuais, mas sim pela elasticidade do espaço enunciativo abrigando diferentes regiões do dizer em dado universo discursivo.

${ }^{20}$ GIP - Grupo de Informação sobre as Prisões - , foi um grupo ativista proposto por Michel Foucault, Pierre Vidal-Naquet e Jean-Marie Domenach, entre 1971-1972, para, através da publicação do resultado de enquetes realizadas dentro do presídio, dar voz aos presos. O objetivo era fazer com que toda população francesa conhecesse a situação miserável do sistema prisional.

${ }^{21}$ Foucault, “Manifesto do GIP” In Ditos e Escritos IV. 2003 
Impunha-se aí, em um engajamento pontual, a urgência de se manifestar tão de perto quanto necessário: estamos sob o signo do 'vigiar de perto'. Nisso consiste o engajamento que alia a ação do jornalista radical ao pensamento do intelectual específico. O primeiro age atirando-se em meio a multidões de revoltosos confrontando um exército pesadamente armado. O segundo, o intelectual específico, compartilha o pensamento acerca do que se passa não só com seus pares assentadas em cátedras universitárias, mas com todos os implicados no ativismo. Dizer "nós", aqui, não é pensar sobre, mas pensar com.

Cabe agora outro exemplo contundente. É quando o filósofo, em uma entrevista acerca da relação entre os intelectuais e os poderes, aludindo ao incômodo que causava sua crítica junto aos agentes penitenciários e psiquiátricos, incidentalmente em seu comentário, conclamava os seus detratores falando assim: “(...) Tentemos agora, juntos elaborar novos modos de crítica, novos modos de questionamentos, tentemos outra coisa. ${ }^{22}$ Marca-se aí a convocatória a fazer da "teoria" e da "prática" uma ação em que o eu do intelectual se estende até abarcar o eu de todo militante envolvido numa luta em sua defesa ou contra o poder. Aos que servem os poderes importa conclamá-los a pensar de outro jeito as questões que gerenciam. Quanto aos que confrontam os poderes urge chamá-los a agir indo além da busca de uma situação ideal. Fica assim posta a ideia de conceber intelectuais e ativistas sociais como ponto único de referência a que se reporta o nós.

Nesta linha, se o "eu”, ainda segundo Benveniste, aponta para aquele que diz como instância de origem da fala no momento em que ela acontece, proponho, como já sinalizei, que mais que expandir o "eu" que diz "eu", o "nós" dilata a instância de onde parte o ato de enunciar, num gesto de conexão de vozes. Exemplo disso é o "nós" dos enunciados finais do Manifesto do GIP:

\begin{abstract}
Não cabe a nós sugerir uma reforma. Queremos apenas fazer conhecer a realidade. (...). Buscaremos todos os meios de informação. (...). Enfim é bom saber o que nos ameaça, mas também é bom saber como se defender. Uma de nossas primeiras tarefas será publicar um pequeno Manuel du parfait arrêté, acompanhado evidentemente de um Avis aux arreteurs. (FOUCAULT, op. cit., p. 2-3)
\end{abstract}

Há um jogo complexo compondo a referência ao "nós", nesta enunciação. Primeiro, porque não designa a soma de "eu (enunciador) + "vocês" (possíveis leitores ou ouvintes). A figuração da cena deste pronunciamento remete a instâncias diferidas de posições de enunciação, isto é, "nós" (GIP) + "eles" (detidos e detentores).

Em segundo lugar, no instante em que o manifesto afirma: "não cabe a nós sugerir uma reforma", este "nós", implicitamente, induz a marcar, mesmo sem explicitação do referente, a terceira pessoa - "eles" -, como o elemento excluído na sua interlocução. Dito de outro modo, Foucault não dá lugar, em sua enunciação, a quem quer que caiba postular reforma. Esta é a posição do terceiro excluído: é falado, mas não fala no manifesto do GIP.

${ }^{22}$ Foucault "O intelectual e os poderes", In Ditos e Escritos VI. Repensar a Politica. Rio de Janeiro: Forense Universitária, 2010. 
Cadernos de ESTUDOS LINGUÍSTICOS (58.3) - set./dez. 2016

Já quando, no manifesto, aparece a frase: "queremos apenas fazer conhecer a realidade", traz para dentro da instância enunciativa o "nós" da referência ao GIP somado ao eles, referência aos detidos, o que concorre para nuançar o emprego do "nós" no final do manifesto: "é bom saber o que nos ameaça". Dizer "nós", neste preciso ponto, é tomar o par pronominal, "nós"/"eles", associando o "nós" do GIP ao "eles" dos detidos. Pode-se descrever, neste fragmento, como o "nós" amplia a extensão do "eu", ponto de origem da enunciação. Em vez de expressar o sentimento solidário de quem, do lado de fora, se preocupa com o problema do sistema prisional, Foucault presentifica a situação dos presos e o envolvimento corporal de todos mediante a pluralização da primeira pessoa - "queremos apenas"/ "... o que nos ameaça".

Realiza-se assim a montagem de uma enunciação que remete ao movimento de denúncia do que sofrem os presos no sistema prisional francês no tempo em que o manifesto é proferido. Trata-se, na dimensão do pensamento foucaultiano, de integrar mais um elemento diferencial ao "nós" do GIP, que já comporta a heterogeneidade dos que agem e falam por si na primeira pessoa do plural. Dessa forma também é que se constitui a espacialidade e a temporalidade onde se incluem os que agem fora e dentro da prisão.

Em síntese, no caso dos proferimentos de Foucault, empregar o pronome pessoal "nós" é ampliar o gesto enunciativo realçando a ressonância dos harmônicos ${ }^{23}$ vindos da composição diferencial dos lugares de enunciação.Refiro-me, no âmbito do grupo de informação sobre as prisões (GIP), aos diferentes componentes da mesma luta: os intelectuais na especificidade de seus campos de saber, militantes em geral e os presos nas condições em que foram condenados. A ação de cada um é, na diversidade de sua pertença social e política, o harmônico a integrar a nota emitida por Foucault em primeira pessoa do plural, dando o tom do ativismo inerente ao GIP: "queremos apenas fazer conhecer a realidade".

\section{CONSIDERAÇÕES ÚLTIMAS}

Partindo de fragmentos de enunciação aleatoriamente colhidos, neste artigo propus que, na voz do filósofo, a primeira pessoa do plural não está como simples polidez majestática ou neutralização moderada de um eu diluindo-se como ponto de origem da enunciação. O "nós" de enunciados como "... o que se passa em torno de nós, o que nós somos" estabelece uma modalidade singular de aproximação entre o enunciador e a realidade de que se ocupa, envolvendo o destinatário a um nível exterior ao que se passa.

${ }^{23}$ Uso o termo harmônico como metáfora retirada da linguagem musical, em que o harmônico é um componente do som ou da nota musical emitida em uma frase melódica. Assim figuro alegoricamente a voz de Foucault dizendo "nós", emissão pronominal que, mantendo a unicidade da emissão, faz multiplicar os componentes de um só ato de enunciação . 
E, se tomarmos, em sua materialidade semântica e sintática, frases como "O futuro é a maneira com que reagimos ao que se passa, é a maneira com que transformamos em verdade um movimento, uma dúvida”, compreende-se que o "nós" funciona conectando o tempo e o espaço no interior de um mesmo ato de enunciação. É dizer que a concordância em primeira pessoa do plural de reagimos, recorta lugares discursivos ligando heterogêneas posições.

De modo que, quando Foucault dizia "nós", não só ressaltava a autonomia e individualidade de cada atuante com quem partilhava suas ações e reflexões, mas sobretudo fazia emergir, performativamente ${ }^{24}$, a linha de fuga na qual dizer "nós, antes que dizer mais de um, é propor e fazer falar em alto volume a possibilidade outra de agir e de pensar. O "nós" sinaliza um percurso convergente de distintas vozes. É preciso lembrar, contudo, que isto não se dá como resultado de trabalho de sutil sobreposição que descreve, por exemplo, a polifonia que Bahktin $^{25}$ tão bem descreve nos romances de Dostoiévski. A fala de Foucault procede antes de tudo pela ampliação de um espaço enunciativo de modo a expor diferenças precisas convergindo na direção de um modo de habitar criticamente questões pontuais do presente criando nele práticas de liberdade que escapam da discursividade dominante na qual debatem entre si as mesmas vozes unidas pela pluralização em primeira pessoa..

Penso que a análise que desenvolvi até aqui pode sintetizar o sentido de proximidade regendo as ações e gestos militantes de Foucault: “... a questão da filosofia é bem a questão desse presente que é nós mesmos". Note-se que a primeira pessoa do plural é proferida ao mesmo tempo com valor dêitico indicando o sujeito que fala e o espaço em que este se situa na enunciação.

Finalmente, ao ouvir ou ler a fala deste filósofo, jogando menos com o conteúdo das palavras e mais com o modo com que as articula, não importa o tempo da história ou espaço geográfico em que voltamos aos seus ditos e escritos, encontramos sempre o Foucault nosso próximo.

\section{REFERÊNCIAS BIBLIOGRÁFICAS}

AGAMBEN, Giorgio. O que resta de Auschwitz: o arquivo e o testemunho (Homo Sacer III). São Paulo: Boitempo Editorial, 2008.

BENVENISTE, É. "Estrutura das relações de pessoa no verbo francês". Problemas de Lingüistica Geral II. Campinas: Pontes, 1995.

BROSSAT, A. Quand Foucault dit “nous”... In http://appareil.revues.org/1265. Acesso em 03/02/2016.

FOUCAULT, M. “A cena da filosofia”. In:Ditos e escritos VII Arte, Epistemologia, Filosofia e História da Medicina. Org. Manuel de Barros da Motta. Tradução de Vera Lucia Avellar Ribeiro. Rio de Janeiro: Forense Universitária, 2011, p. 222-247.

\footnotetext{
${ }^{24}$ Alusão ao conceito cunhado por John Austin, para quem o performativo é um ato linguístico que não descreve, mas instaura um estado de coisas no mesmo tempo e espaço em que é proferido.

${ }^{25}$ BAKHTIN, Mikhail 2008. Problemas da poética de Dostoiévski. Tradução de Paulo Bezerra. Rio de Janeiro: Forense Universitária.
} 
$\overline{\text { FOUCAULT, M., Historia da Sexualidade I. A vontade de saber. Trad. Costa Albuquerque e Guilhon }}$ Albuquerque. Rio de Janeiro, Edições Graal, 1979.

FOUCAULT, M., "Uma revolta a mãos nuas". In Ditos e escritos VI. Repensar a politica. Rio de Janeiro, Forense Universitária, 2010, p. 241, 244.

FOUCAULT, M. “Afilosofia analítica da política (1978)". In: Ditos e escritos V. Rio de Janeiro: Forense Universitária, 2004, p. 37-55.

FOUCAULT, M. "Foucault estuda a razão de Estado". In: Ditos e escritos IV. Estratégia-PoderSaber,Rio de Janeiro: Forense Universitária, 2003, p. 317-322.

FOUCAULT, M. "Manifesto do GIP” In: Ditos e Escritos IV. Estratégia, Poder-Saber. Org. Manoel Barros da Motta. Trad. Vera Lúcia Avellar Ribeiro. Rio de Janeiro: Forense Universitária, 2003, p.1-3.

FOUCAULT, M. “O intelectual e os poderes”, In: Ditos e Escritos VI. Repensar a Politica.Org. Manoel Barros da Motta. Trad. Ana Lucia Paranhos Pessoa. Rio de Janeiro: Forense Universitária, 2010, p. 371-376.

FOUCAULT, M. A arqueologia do saber. Trad. Luiz Felipe Baeta Neves.Rio de Janeiro: ForenseUniversitária, 1986.

FOUCAULT, M. As palavras e as coisas, uma arqueologia das ciências. Trad. Salma Tannus Muchail. São Paulo: Martins Fontes.

FOUCAULT, M. História da Loucura na Idade Clássica.Trad. José Teixeira Coelho Netto. São Paulo: Perspectiva, 1978. 